\title{
Reduction of Total Harmonic Distortion in Cascaded H-Bridge Inverter by Pattern Search Technique
}

\author{
Suresh N. ${ }^{1}$, R. Samuel Rajesh Babu ${ }^{2}$ \\ ${ }^{1}$ Faculty of Electrical and Electronics Engineering, Sathyabama University \\ ${ }^{2}$ Associate Professor, Departement of Electronics and Instrumentation Engineering, Sathyabama University
}

\begin{tabular}{l} 
Article Info \\
\hline Article history: \\
Received Aug 25, 2016 \\
Revised Sep 8, 2017 \\
Accepted Sep 29, 2017 \\
\hline
\end{tabular}

\section{Keyword:}

Cascaded HBridge inverter Optimization techniques Pattern search algorithm Switching angle

Total harmonic distortion

\begin{abstract}
Pattern Search technique can be used to find the solution for the optimization problem. In this paper, pattern search algorithm has been utilized to calculate the switching angles for the cascaded H-bridge inverter with the consideration of minimizing total harmonic distortion. Mathematical equations for the optimization problem were formulated by fourier analysis technique. Lower order harmonics such as third, fifth, seventh, ninth and eleventh order harmonics were taken into account to mitigate the total harmonic distortion of the inverter. Simulations have been carried out for thirteen level, fifteen level and seventeen level cascaded H-bridge inverter using matlab software. Total harmonic distortion of voltage and current for resistive load, resistive-inductive load and motor load were analyzed.
\end{abstract}

Copyright $(0) 2017$ Institute of Advanced Engineering and Science. All rights reserved.

\section{Corresponding Author:}

Suresh N.,

Faculty of Electrical and Electronics Engineering,

Sathyabama University,

Sholinganallur, Chennai-600119, Tamilnadu, India.

Email: mailtonsuresh@gmail.com

\section{INTRODUCTION}

In developing countries, electrical power deficit is a major problem. The gap between the supply and the demand widens with the advent of new machines and devices which rely on electricity. Most of the machines used in the manufacturing sector and home appliances by the consumers like air-conditioner, refrigerator, iron boxes, heaters, etc. require power for its operation. To cope up with the demand, immense research is being carried out in the field of producing electrical power from solar energy, wind energy etc. Power produced from the renewable energies is of direct current. But electricity of alternating current type is utilized by many machines in the automation industry. Hence it is necessary to boost the direct current [1] and convert it into alternating current. When converting the d.c into a.c by the inverters, distortions were produced known as harmonics. A harmonic component in a power system is a sinusoidal component of a periodic waveform having a frequency that is an integral multiple of the fundamental frequency [2]. These harmonic components give rise to undesirable effects [3] on conductors, transformers, circuit breakers, fuses, rotating machines, telephone lines, etc. Harmonics can measured by a parameter called Total Harmonic Distortion (THD) [4]. Since THD affects the operation of machines, it is important to mitigate them.

Numerous inverters were designed by the researchers with the intention of reducing harmonics. One such inverter is the multilevel inverter. For medium and high power applications multilevel inverters are applied. Various topologies of multilevel inverters such as cascaded H-bridge inverter, diode-clamped inverter, capacitor-clamped inverter were discussed [5]. THD generated by the diode-clamped inverter and capacitor-clamped inverter is more compared to the cascaded H-bridge inverter for the same number of levels [6]. Hence cascaded H-bridge inverters were considered for analysis. 
Cascaded H-bridge inverter gets the input from several dc sources and converts it into stepped ac waveform. The steps are called level. As the number of level increases, the sinusoidal waveform will be produced with reduced THD. The switching angles for the inverter have to be estimated with the aim of minimizing harmonics. Many techniques were proposed in the literature to mitigate harmonics. In [7] Newton-Raphson method was used to calculate switching angle for the multilevel inverter. The NR method is capable of finding solution only in the limited range and possibility of getting stuck at local optima. Ant colony optimization [8], Firefly algorithm [9], Bacterial Foraging algorithm [10] Frog Leaping algorithm [11], Artificial Bee Colony algorithm [12], Particle Swarm Optimization algorithm [13], Simulated Annealing [14] and Genetic algorithm [15] were applied for harmonic reduction in multilevel inverter. But the THD reduction does not comply with the IEEE standard 519. Walsh function method has been reported in [16]. Here switching angles are obtained by solving linear equations. The method fails [17] if it is required to find more angles in the same interval. The energy management system with cascaded multilevel inverter has been reported in [18]. Harmonic analysis of seven and nine level inverter were carried out in [19]. The optimization methods applied for harmonic reduction one way or the other leads to premature convergence, difficulty in finding the initial guess, THD not compliance with the IEEE 519 standard, inconsistency of the optimal solution for the varying modulation index were the major problems faced.

In this paper pattern search algorithm has been utilized to calculate the switching angle for the cascaded H-bridge inverter with the aim to minimize the total harmonic distortion. Matlab software was used to simulate the thirteen level, fifteen level and seventeen level inverter with resistive load, resistive-inductive load and motor load.

\section{CASCADED H-BRIDGE INVERTER}

Cascaded H-bridge inverter acquires the input from manyl DC sources and generates a stepped waveform. As the number of levels of the inverter increases, the waveform approaches sinusoid reducing the total harmonic distortion. A k-level inverter consist of (k-1)/2 H-bridges. Four switching devices are required for each bridge. Switching devices can be of IGBT, Power MOSFET, SCR etc. Here SCR has been used as a switching device. Thirteen level inverter with resistive inductive load is shown in the Figure 1. The inverter consist six H-bridges connected in series and hence it contains twenty four switches.

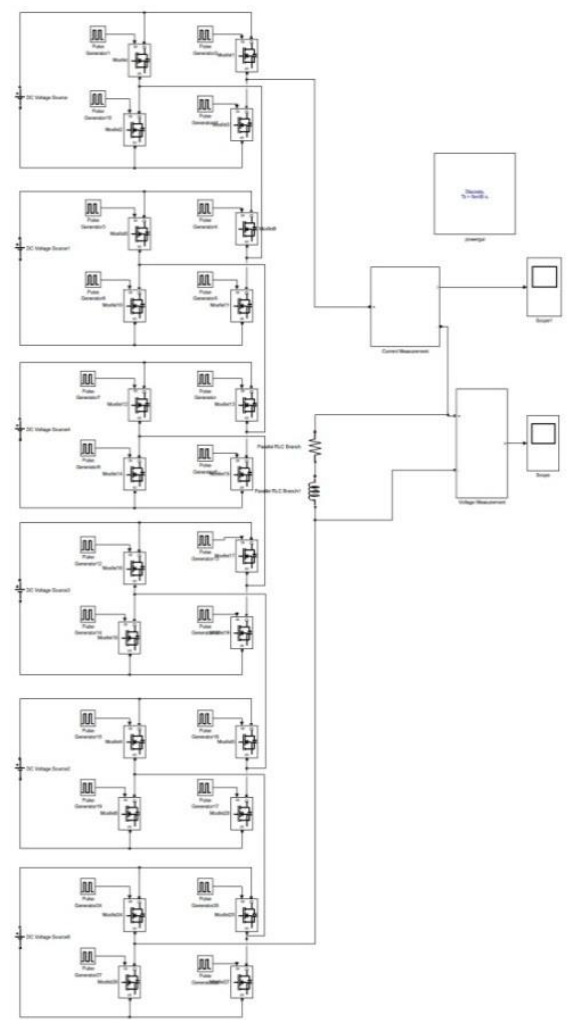

Figure 1. 13-level inverter with RL load 
Mathematical equations for minimizing the harmonics have been formulated by fourier analysis The following equation represents fundamental component, third harmonics, fifth harmonics, seventh harmonics, ninth harmonics and eleventh harmonics for the 13-level inverter

Fundamental Component

$$
\frac{4}{\pi \sqrt{2}}\left(V_{1} \cos \theta_{1}+V_{2} \cos \theta_{2}+V_{3} \cos \theta_{3}+V_{4} \cos \theta_{4}+V_{5} \cos \theta_{5}+V_{6} \cos \theta_{6}\right)=230 ;
$$

Third Harmonic Equation

$$
\mathrm{V}_{1} \cos 3 \theta_{1}+\mathrm{V}_{2} \cos 3 \theta_{2}+\mathrm{V}_{3} \cos 3 \theta_{3}+\mathrm{V}_{4} \cos 3 \theta_{4}+\mathrm{V}_{5} \cos 3 \theta_{5}+\mathrm{V}_{6} \cos 3 \theta_{6}=0
$$

Fifth Harmonic Equation

$$
\mathrm{V}_{1} \cos 5 \theta_{1}+\mathrm{V}_{2} \cos 5 \theta_{2}+\mathrm{V}_{3} \cos 5 \theta_{3}+\mathrm{V}_{4} \cos 5 \theta_{4}+\mathrm{V}_{5} \cos 5 \theta_{5}+\mathrm{V}_{6} \cos 5 \theta_{6}=0
$$

Seventh Harmonic Equation

$$
\mathrm{V}_{1} \cos 7 \theta_{1}+\mathrm{V}_{2} \cos 7 \theta_{2}+\mathrm{V}_{3} \cos 7 \theta_{3}+\mathrm{V}_{4} \cos 7 \theta_{4}+\mathrm{V}_{5} \cos 7 \theta_{5}+\mathrm{V}_{6} \cos 7 \theta_{6}=0 ;
$$

Ninth Harmonic Equation

$$
\mathrm{V}_{1} \cos 9 \theta_{1}+\mathrm{V}_{2} \cos 9 \theta_{2}+\mathrm{V}_{3} \cos 9 \theta_{3}+\mathrm{V}_{4} \cos 9 \theta_{4}+\mathrm{V}_{5} \cos 9 \theta_{5}+\mathrm{V}_{6} \cos 9 \theta_{6}=0
$$

Eleventh Harmonic Equation

$$
\mathrm{V}_{1} \cos 11 \theta_{1}+\mathrm{V}_{2} \cos 11 \theta_{2}+\mathrm{V}_{3} \cos 11 \theta_{3}+\mathrm{V}_{4} \cos 11 \theta_{4}+\mathrm{V}_{5} \cos 11 \theta_{5}+\mathrm{V}_{6} \cos 11 \theta_{6}=0
$$

Where $V_{1}, V_{2}, V_{3}, V_{4}, V_{5} \& V_{6}$ are the input dc voltages for six H-brdge inverters. $\theta_{1}, \theta_{2}, \theta_{3}, \theta_{4}, \theta_{5} \& \theta_{6}$ are the switching angles for six $\mathrm{H}$-bridge inverters

\section{PATTERN SEARCH ALGORITHM}

Pattern search algorithm can be used to find the minimum of the function called objective function with constraints. It takes the objective function with the initial random values. Pattern search method performs the sequence of iterations for convergence. Once finite number of iteration is reached it switches to the lower cost function. Mesh size plays a role in setting the search along the search direction. The default value of the mesh size is one. Sometimes solution got may not be optimum. So to improve optimality of the solution mesh scaling has to be done. The number of function evaluation will be minimum with appropriate scaling, reducing the computation time. The Pattern Search algorithm [20] is given by

Let $\mathrm{x}_{0} \in \mathrm{R}^{\mathrm{n}}$ and $\Delta_{0}>0$ be given.

For $\mathrm{k}=0,1, \ldots$,

(a) Compute $\mathrm{f}\left(\mathrm{x}_{\mathrm{k}}\right)$.

(b) Determine a step $\mathrm{s}_{\mathrm{k}}$ using an exploratory moves algorithm.

(c) Compute $\rho_{\mathrm{k}}=\mathrm{f}\left(\mathrm{x}_{\mathrm{k}}\right)-\mathrm{f}\left(\mathrm{x}_{\mathrm{k}}+\mathrm{s}_{\mathrm{k}}\right)$.

(d) If $\rho_{k}>0$ then $x_{k+1}=x_{k}+s_{k}$. Otherwise $x_{k+1}=x_{k}$.

(e) Update $\mathrm{C}_{\mathrm{k}}$ and $\Delta_{\mathrm{k}}$.

To define a particular pattern search method, it is necessary to specify the basis matrix $\mathrm{B}$, the generating matrix $\mathrm{C}_{\mathrm{k}}$, the exploratory moves to be used to produce a step $\mathrm{s}_{\mathrm{k}}$, and the algorithms for updating $\mathrm{C}_{\mathrm{k}}$ and $\Delta_{\mathrm{k}}$. Here pattern search algorithm has been applied to determine the switching angles of the cascaded H-bridge inverter with the aim to minimize total harmonic distortion.

\section{RESULTS AND DISCUSSION}

The switching angles for the cascaded H-bridge inverter have been obtained by pattern search method through Matlab software. Fitness function based on fundamental component and constraint function based on harmonic components were formulated using fourier analysis simulation was done for thirteen 
level, fifteen level and seventeen level inverter considering various loads such as resistive load, resistiveinductive load and motor load.

Simulation results for the cascaded H-bridge inverter with various levels with $\mathrm{R}$ load, RL load and motor load were shown in Figure 2, Figure 3 and Figure 4 respectively. Voltage THD and current THD with associated waveforms for 13-level inverter RL load were shown in Figure 5 and Figure 6 respectively. To investigate the consistency of the pattern search algorithm, it has been run many times and the correspond THD values are plotted in Figure 7 and Figure 8. From the results it is clear that as the level of the inverter increases THD decreases. The pattern search method of calculating the switching angles for the inverter is effective in reducing the total harmonic distortion in compliance to the IEEE 519 standard.

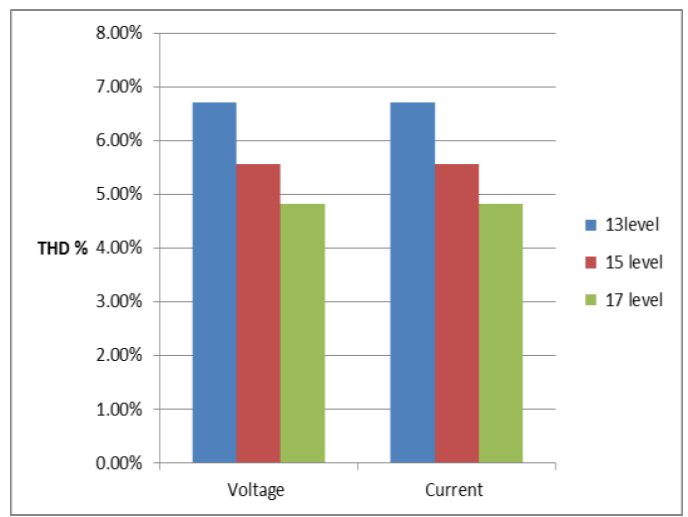

Figure 2. Comparison of voltage and current THD for 13, 15 and 17-level inverter for R load

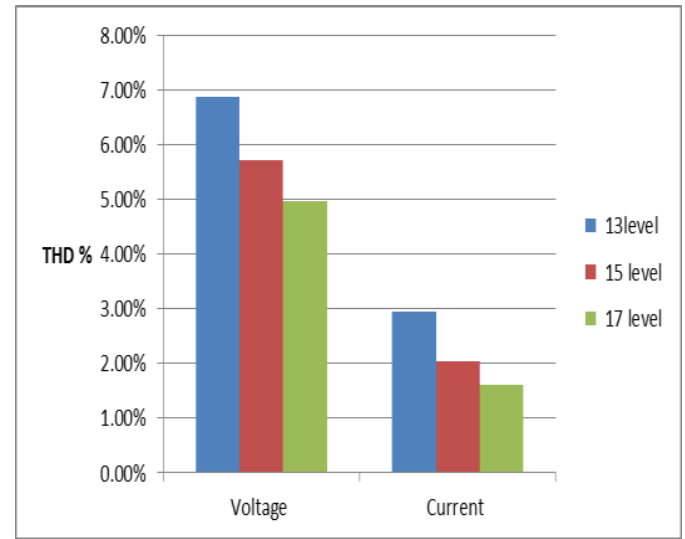

Figure 3. Comparison of voltage and current THD for 13, 15 and 17-level inverter for RL load

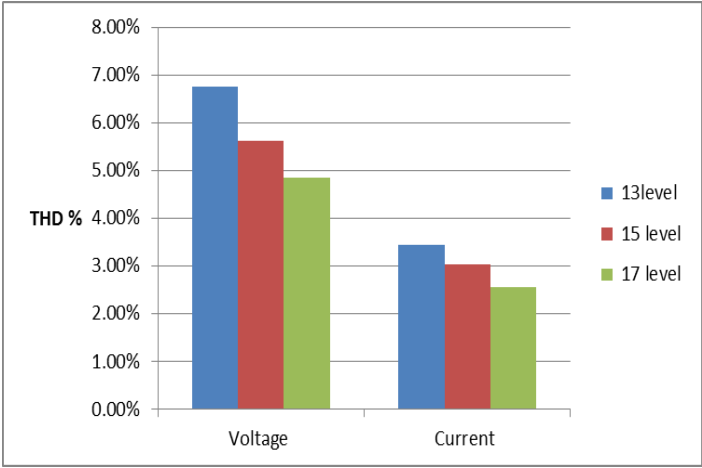

Figure 4. Comparison of voltage and current THD for 13, 15 and 17-level inverter for Motor load 

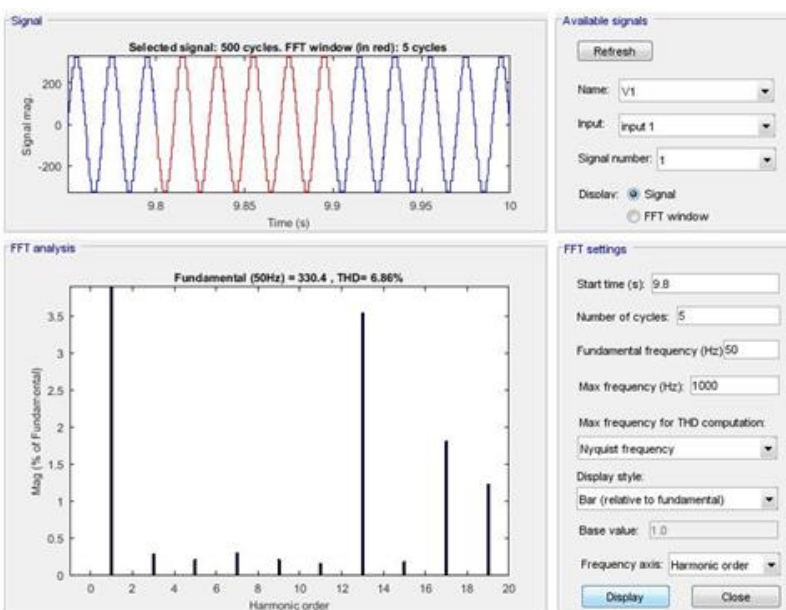

Figure 5. Voltage THD of 13-level inverter with RL load
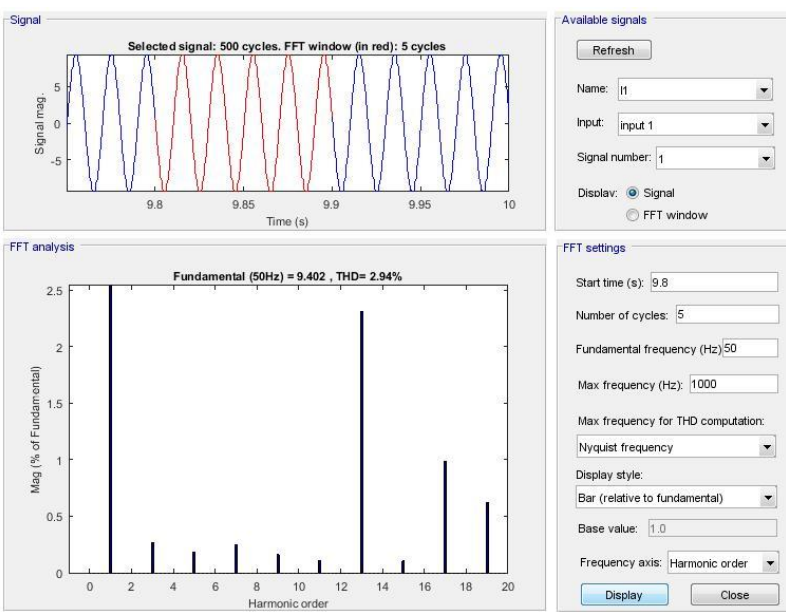

Figure 6 Current THD of 13-level inverter with RL load

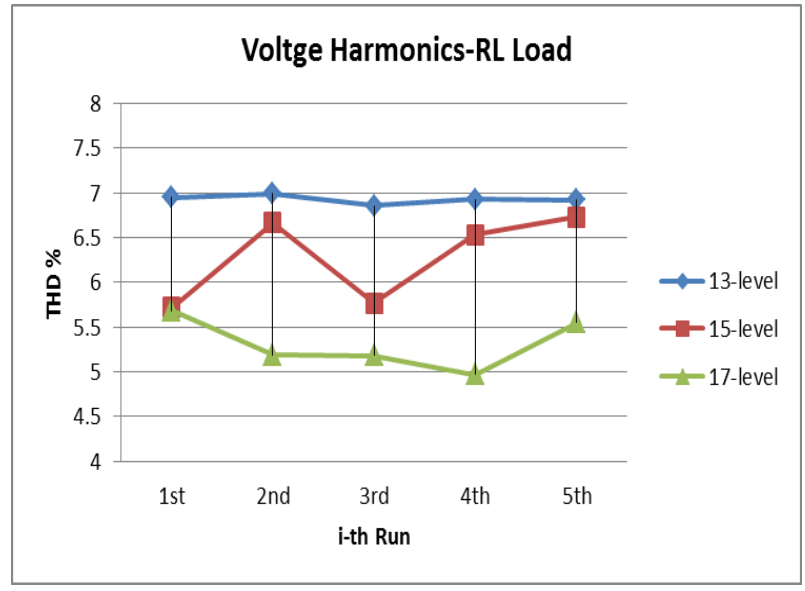

Figure 7. 13,15,17 Level inverter RL load -Voltage THD\% comparison 


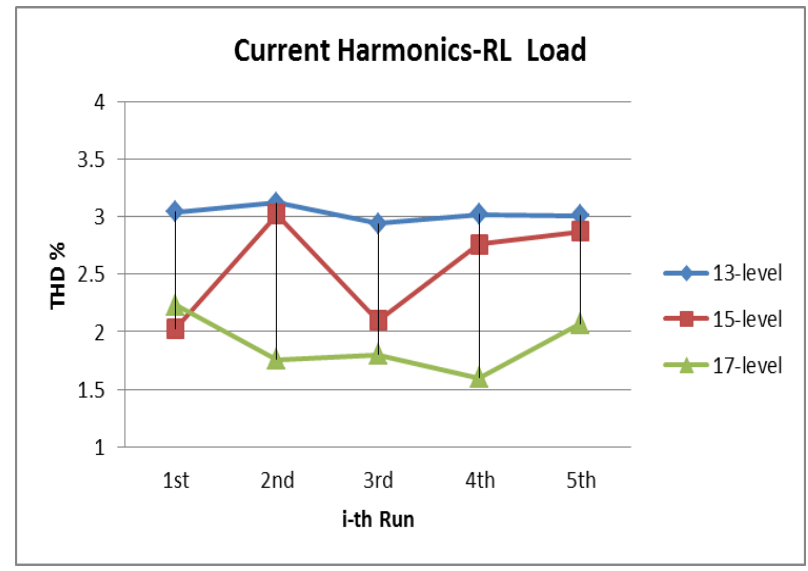

Figure 8. 13,15,17 Level inverter RL load -Current THD\% comparison

\section{CONCLUSION}

Cascaded H-bridge inverters with thirteen level, fifteen level and seventeen level have been simulated with matlab for harmonic mitigation. The switching angles for the inverter calculated by pattern search optimization algorithm. The results conforms the effectiveness of the pattern search algorithm to find out the switching angles with the objective of THD minimization.

\section{REFERENCES}

[1] R. S. R. Babu, et al., "A Closed Loop Control of Quadratic Boost Converter Using PID Controller," IJE transactions B: Applications, vol. 27, pp. 1653-1662, 2014.

[2] R. D. Henderson and P. J. Rose, "Harmonics: The effects on power quality and transformers," IEEE Transactions on Industry Applications, vol. 30, pp. 528-32, 1994.

[3] N. Suresh and R. S. R. Babu, "Review on Harmonics and its Eliminating Strategies in Power System," Indian Journal of Science and Technology, vol. 8, pp. 1-9, 2015.

[4] D. Shmilovitz, "On the definition of total harmonic distortion and its effect on measurement interpretation," IEEE Transactions on Power Delivery, vol. 20, pp. 526-528, 2005.

[5] J. Rodríguez, et al., "Multilevel Inverters: A Survey of Topologies, Controls, and Applications," IEEE Transactions on Industrial Electronics, vol. 49, pp.724-738, 2002.

[6] M. G. V. Kumar, et al., "Comparison of multilevel inverters with PWM Control Method," International Journal of IT, Engineering and Applied Sciences Research, vol. 1, pp. 25-29, 2012.

[7] T. R. Sumithira, et al., "Elimination of Harmonics in Multilevel Inverters Connected to Solar Photovoltaic Systems Using ANFIS: An Experimental Case Study," Journal of Applied Research and Technology, vol. 11, pp. 124-132, 2013.

[8] I. Adeyemo, et al., "Ant Colony Optimisation Approach to Selective Harmonic Elimination in Multilevel Inverter," IMPACT: International Journal of Research inEngineering \& Technology, vol. 3, pp. 31-42, 2015.

[9] M. G. Sundaria, et al., "Application of improved firefly algorithm for programmed PWM in multilevel inverter with adjustable DC sources," Applied Soft Computing, 2015.

[10] T. S. Babu, et al., "Selective voltage harmonic eliminationin PWM inverter using bacterial foraging algorithm," Swarm and Evolutionary Computation, 2015.

[11] H. Lou, et al., "Fundamental modulation strategy with selective harmonic elimination for multilevel inverters," IET Power Electron, vol.7, pp. 2173-81, 2014.

[12] S. Biswasa, "Amitava Chatterjeeb, Swapan Kumar Goswamib, An artificial bee colony-least square algorithm for solving harmonic estimation problems," Applied Soft Computing, vol. 13, pp. 2343-2355, 2013.

[13] Adeyemo I. A., et al., "Particle Swarm Optimization Approach to Harmonic Reduction in Voltage Source Multilevel Inverter," International Journal of Soft Computing and Engineering, vol/issue: 5(5), pp. 1-5, 2015.

[14] L. G. Sugumaran, et al., "Simulated Anealing Algorithm Based Optimization for Cascaded Multilevel Inverters," International Journal on Applications in Electrical and Electronics Engineering, vol. 1, pp. 32-35, 2015.

[15] G. Gera, et al., "Reduction of Total Harmonic Distortion in Power Invertors Using Genetic Algorithm," Int. Journal of Engineering Research and Applications, vol. 3, pp. 761-766, 2013.

[16] F.Swift, et al., "A new Walsh domain technique of harmonic elimination and voltage control in pulse-width modulated inverters," IEEE Trans.Power Electron, vol. 8, pp. 172-185, 1993.

[17] L. T. Juu, et al., "Inverter harmonic reduction using Walsh function harmonic elimination method," IEEE Trans.Power Electron, vol. 12, pp. 971-982, 1997.

[18] R. N. Kumar and J. Baskaran, "Energy Management system for Hybrid RES with Hybrid Cascaded Multilevel inverter," International Journal of Electrical and Computer Engineering, vol. 4, pp. 24-30, 2014. 
[19] C. Gupta, et al., "Harmonic Analysis of Seven and Nine Level Cascade Multilevel Inverter using Multi Carrier PWM Technique," International Journal of Power Electronics and Drive Systems, vol. 5, pp. 76-82, 2014.

[20] V. Torczon, "On the Convergence of Pattern Search Algorithms," Society for Industrial and Applied Mathematics, vol. 7, pp. 1-25, 1997.

\section{BIOGRAPHIES OF AUTHORS}

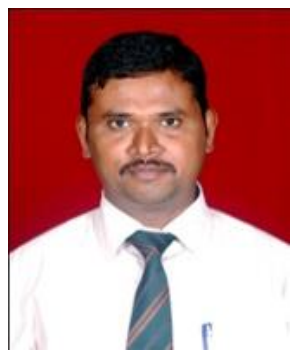

Mr. N. Suresh has completed B.E from Anna university in 2007. He obtained M.E degree in the field of control and instrumentation from College of Engineering, Guindy Anna University in 2009. Presently, He is working as Assistant Professor in Sathyabama University, Chennai and doing research in power electronics. His areas of interest are power electronics, control engineering and Embedded Systems.

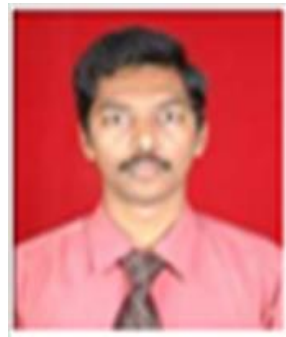

Dr. R. Samuel Rajesh Babu has obtained his B.E Degree from Madras University in 2003. He obtained his M.E degree from Anna University in 2005. He obtained his Ph.D degree from Sathyabama University in 2013. Presently he is a Associate Professor in Sathyabama University. His areas of interest are Power Electronics and Digital Protection. 